\title{
Article \\ Productivity of Rainfed Winter Wheat with Direct Sowing and Economic Efficiency of Diversified Fertilization in Arid Region of South Kazakhstan
}

\author{
Sagadat Turebayeva ${ }^{1}$, Aigul Zhapparova ${ }^{1}$, Akbota Yerkin ${ }^{2}$, Khaiyrnisa Aisakulova ${ }^{3}$, Gainiya Yesseyeva ${ }^{4}$, \\ Anuarbek Bissembayev ${ }^{5}$ and Elmira Saljnikov $6,7, *$ (D)
}

1 Department of Soil Science and Agrochemistry, Faculty of Agrobiology, Kazakh National Agrarian Research University, Abai Avenue 8, Almaty 050010, Kazakhstan; tyrebaeva_saga@mail.ru (S.T.); aigul7171@inbox.ru (A.Z.)

2 Kazakh Research Institute of Plant Protection and Quarantine Named after Zh. Zhiembaev, 1 Kultobe Street, Rakhat, Almaty 050010, Kazakhstan; yerkinova.akbota@bk.ru

3 Laboratory of Agrochemistry and Quality of Fruit and Vegetable Products, Kazakh Research Institute of Fruit and Viticulture, 238 Gagarin Avenue, Almaty 050060, Kazakhstan; hairinissa@mail.ru

4 Department of Standardization and Food Technologies, Kostanay Engineering and Economics University Named after M. Dulatov, Kostanay 110000, Kazakhstan; gainia@mail.ru

check for

updates

Citation: Turebayeva, S.;

Zhapparova, A.; Yerkin, A.;

Aisakulova, K.; Yesseyeva, G.; Bissembayev, A.; Saljnikov, E. Productivity of Rainfed Winter Wheat with Direct Sowing and Economic Efficiency of Diversified Fertilization in Arid Region of South Kazakhstan. Agronomy 2022, 12, 111. https://doi.org/10.3390/ agronomy12010111

Academic Editors: Othmane Merah, Purushothaman

Chirakkuzhyil Abhilash, Magdi

T. Abdelhamid, Hailin Zhang and Bachar Zebib

Received: 26 November 2021

Accepted: 28 December 2021

Published: 2 January 2022

Publisher's Note: MDPI stays neutral with regard to jurisdictional claims in published maps and institutional affiliations.

Copyright: (C) 2022 by the authors. Licensee MDPI, Basel, Switzerland. This article is an open access article distributed under the terms and conditions of the Creative Commons Attribution (CC BY) license (https:/ / creativecommons.org/licenses/by/ $4.0 /)$.
5 LLP, 1419 Office, Scientific and Production Centre for Animal Husbandry and Veterinary, Kenesary Street 40, Nur-Sultan 010000, Kazakhstan; npczhiv@mail.ru

6 Department of Pedology, Institute of Soil Science, Teodora Drajzera 7, 11000 Belgrade, Serbia

7 Mitscherlich Academy for Soil Fertility (MITAK) GmbH, Prof.-Mitscherlich-Allee 1, 14641 Paulinenaue, Germany

* Correspondence: soils.saljnikov@gmail.ru or soils.saljnikov@gmail.com; Tel.: +381-607409123

\begin{abstract}
Reduced soil tillage is a powerful means to mitigate soil degradation. However, in arid climates, no-till rainfed technologies often result in yield drop due to lack of soil moisture and mineral nutrition. Rainfed production of winter wheat using direct sowing and diversified fertilization in South Kazakhstan was studied in 2019-2020. Eight field-scale treatments using nitrogen and phosphorus fertilizers were studied for biometric parameters of winter wheat. An economic profitability of the amendments used was assessed. The soil managed to accumulate productive moisture to support plants' needs during formation of productive organs. Use of phosphorus fertilizer at direct sowing accelerated grain maturation, and the combination of phosphorus and nitrogen fertilizer lengthened the growing season. The highest production cost of 1 tonne of grain was in the plots that did not receive any amendments, and the lowest cost was in the treatment with use of plant growth stimulants together with micronutrient fertilizer. For the first time, optimization of the soil nutritional regime with consideration of the biological and phenological demands allowed for the balance of the plant nutrition and cost efficiency of grain production with direct sowing of winter wheat in dry conditions in South Kazakhstan.
\end{abstract}

Keywords: direct sowing; winter wheat; phosphorus; micronutrients; growth stimulant; soil moisture

\section{Introduction}

Significant areas of agricultural soils are degraded due to improper management [1-7]. World experience shows that traditional farming systems, even with their possible high productivity, lead to soil degradation problems and reduced cost efficiency [8-13]. For example, frequent bare fallowing and conventional methods of soil cultivation have been attributed to the main causal factors in the manifestation of soil erosion processes [13-16]. Traditional tillage accumulates in a small amount of crop residues on the field, accelerates decomposition of SOM and affects soil structure, which accelerates depletion of soil fertility and leads to an increased risk of erosion. Conservation agriculture, such as zero and 
minimum tillage, are firmly gaining a place in many countries of the world. These lowimpact technologies preserve stubble on the soil surface, decrease the weight load on the soil, decrease the mineralization of soil organic matter, and thus contribute to carbon sequestration goals [17-19]. The mulch protective layer on the surface of the field begins to work when the chopped mass accumulates from 3 to 5 tonnes per hectare. The accumulation of such amount requires a long period and stable high yield of agricultural crops [20-22]. The larger amount of crop residues usually translates into improved crop growth [23].

In the rainfed agriculture of the South Kazakhstan, the main limiting factor for the growth and development of agricultural crops is soil moisture, since during the growing season there is an insufficient amount of atmospheric precipitation, and the moisture reserve in the soil accumulated in the autumn-winter period does not satisfy the water demand of crops. Winter wheat is a popular crop in this region and it is grown under dry farming without irrigation. Conservation farming systems, such as minimum and zero tillage with direct sowing of cereals, can significantly help in solving soil moisture deficit problems, which is especially important for farmers in dry and hot regions of Kazakhstan. These technologies preserve plant mulch on the soil surface thus reducing the evaporation of soil moisture by $60-70 \%$ and providing guaranteed uniform plant shoots [18,24].

An important factor for increasing the efficiency of zero-till technology is an optimization of plant nutrition [25-29]. The balanced fertilization implies that crops are adequately supplied with nutrients at every stage of growth and development. And at the same time, nutrient supply should avoid any over or under-supply in order to ensure safe and sufficient grain yield while minimising environmental impacts.

Among the most pressing problems associated with the direct sowing of cereals, special attention is drawn to a plant protection system. Some authors argue that zero cultivation technology leads to a strong increase in plant damage by phytopathogens due to an increase in the amount of plant residues on the surface [30-32]. Other scientists believe that with zero tillage technologies, the damage caused by root rot of plants is lower than with traditional soil tillage. In the conditions of South Kazakhstan, with direct sowing of winter wheat, more than 30 species of weeds can be found [33-35]. Often with traditional crop technology, weed control is achieved exclusively with herbicides. This over-reliance on herbicides in traditional agriculture is posing new and complex problems, including the rapid development and spread of herbicide-resistant weeds, pollution of the environment and the food chain with pesticides. To minimize these risks, it is necessary to study and apply new generation weed-control preparats that are suitable for green farming.

From an economical point of view, direct sowing technology reduces cost of fuel and lubricant, and reduces energy and resource consumption. From an environmental point of view, it contributes to preservation of soil moisture and ultimately decreasing soil degradation risks by improving soil physical and biological properties [11,36,37].

Although many studies were devoted to the topic under consideration; nevertheless, there is still much debate about the impact of zero tillage on soil properties $[38,39]$ and mitigation of climate change [23,40]. In South Kazakhstan, the problems of resource-saving technology for the cultivation of rainfed winter wheat with direct sowing is one of the many priority areas, which is only in the development stage. Under insufficient precipitation, introduction of no-till technologies is highly challenging and requires detailed studies in order to develop an optimal technology for obtaining both satisfactory and economically profitable crop yield, and at the same time maintain soil quality. A more detailed study and justification of the use of macro and micro fertilizers, growth stimulants and the identification of the most optimal doses and timing of their application in dry farming with direct sowing of cereals is a highly relevant issue.

Therefore, the development of cultivation approaches for direct sowing of rainfed winter wheat with the choice of the most rational doses of mineral fertilizers, micronutrient fertilizers and growth stimulants and with testing of new generation herbicides are of particular interest and have an important practical significance in the production of winter 
wheat grain in Kazakhstan and central Asian regions. To achieve this goal, the following specific tasks were set to study:

(1) Growth and development of rainfed winter wheat, depending on the dose and time of fertilization in a "zero" till system in dry climate of South Kazakhstan;

(2) Formation of the yield structure indicators depending on the soil moisture and fertilization of rainfed winter wheat in a "zero" till system;

(3) Economic efficiency of fertilizers used in the agro-technological system of direct sowing of winter wheat in dry climate of South Kazakhstan.

\section{Materials and Methods}

\subsection{Description of the Experimental Site}

The soil and climatic conditions of South Kazakhstan region are distinguished by a variety of relief (deserts, foothills and mountains). The mountains of the Talas Altai are connected with the western ridges of the Tien Shan, the north-western part of the region is connected with the sandy desert, Betpak steppe. The studied area is situated on a semi-desert climate, which is characterized by a pronounced continentality, dryness and an abundance of warmth. High continentality manifests itself in sharp temperature contrasts between day and night, winter and summer. The average temperature of the coldest month is from +2 to $-5{ }^{\circ} \mathrm{C}$, the warmest $-26-30{ }^{\circ} \mathrm{C}$. Summers are hot, long and extremely dry. The duration of the period with temperatures $>10^{\circ} \mathrm{C}$ is $170-245$ days; the sum of temperatures for this period is $3400-5800{ }^{\circ} \mathrm{C}$. Winter in the region is short and mild, with frequent thaws. Aridity is one of the main distinguishing features of the region's climate. The annual amount of precipitation is $100-250 \mathrm{~mm}$. Precipitation is distributed extremely unevenly over the seasons. Two precipitation maxima are noted: the main primary, sharply expressed is in the spring and the secondary is in the fall. The evaporation rate is $1000-1700 \mathrm{~mm}$ and moisture coefficient is $0.12-0.33$.

The soil cover of the study area is represented by ordinary sierozem [41] and Calcisols [42], developed on a thick loess- loams and sandy loams. These soils are light, friable, calcareous from the surface with an undifferentiated profile, formed in desert steppes (semi-deserts) of the South Kazakhstan region. The flora of this region is represented by ephemeral plants forming a variety of meadows.

The research was carried out in 2019 and 2020, at the stationary experimental fields of the South-Western Research Institute of Livestock and Plant Breeding located near Shymkent City $\left(42^{\circ} 29^{\prime} 90^{\prime \prime} \mathrm{N}\right.$ and $\left.69^{\circ} 70^{\prime} 43^{\prime \prime} \mathrm{E}\right)$ at an altitude of about $650-800 \mathrm{~m}$ above sea level. The growing crop was winter wheat (Triticum durum L.), variety Steklovidnaya 24 and grown in the conditions of rainfed agriculture.

\subsection{Experimental Design}

A standard design for agricultural experiments was applied, where each plot's size was $5.6 \times 10 \mathrm{~m}$ plotted in randomized complete blocks in four replications. Field experiments on the use of fertilizers for direct sowing of winter wheat were laid according to the following scheme (Table 1).

\subsection{Laboratory and Field Methods}

The moisture content and reserves of productive moisture in the soil layers were determined at the ends of the first, second and third 10-day periods of each month, during the winter wheat vegetation to a depth of $1 \mathrm{~m}$, every $10 \mathrm{~cm}$ [43]. The determination of soil moisture was carried out by the thermostat-weight method. For sampling, a $100 \mathrm{~cm}$ long sampling drill was used, on which marks were applied every $10 \mathrm{~cm}$.

Phenological observations were carried out according to the date of the onset of the developmental phases: sprouting, tillering, booting, earing, milk maturity, wax maturity and full maturity. The sprouting phase was recorded when an awl or the first true leaf appeared on the soil surface. The autumn tillering phase was observed when 3 lateral shoots appeared. The booting phase was recorded with the growth of the lowest internode 
of the stem. The heading phase was recorded when inflorescences of an ear appeared from the axils of the upper leaf.

Table 1. Design of the field experiment with direct sowing of winter wheat with various fertilization in South Kazakhstan.

\begin{tabular}{|c|c|c|c|}
\hline No & & Treatments & Fertilizer Application Term \\
\hline 1 & control & No fertilization & \\
\hline 2 & $\mathrm{P}_{30}$ & Phosphorous fertilizer $30 \mathrm{~kg} \mathrm{ha}^{-1}$ & at direct sowing \\
\hline 3 & $\mathrm{P}_{45}$ & Phosphorous $45 \mathrm{~kg} \mathrm{ha}^{-1}$ & at direct sowing \\
\hline 4 & $\mathrm{P}_{30}+\mathrm{N}_{50}$ & $\begin{array}{l}\text { Phosphorous } 30 \mathrm{~kg} \mathrm{ha}^{-1} \\
\text { Nitrogen } 50 \mathrm{~kg} \mathrm{ha}^{-1}\end{array}$ & $\begin{array}{c}\mathrm{P}_{30} \text {-at direct sowing } \\
\mathrm{N}_{50} \text { at the tillering phase in early spring }\end{array}$ \\
\hline 5 & $\mathrm{P}_{30}+\mathrm{N}_{70}$ & $\begin{array}{l}\text { Phosphorous } 30 \mathrm{~kg} \mathrm{ha}^{-1} \\
\text { Nitrogen } 70 \mathrm{~kg} \mathrm{ha}^{-1}\end{array}$ & $\begin{array}{l}\quad \mathrm{P}_{30} \text {-at direct sowing } \\
\mathrm{N}_{70} \text {-at the tillering phase in early spring }\end{array}$ \\
\hline 6 & $\mathrm{P}_{45}+\mathrm{N}_{50}$ & $\begin{array}{l}\text { Phosphorous } 45 \mathrm{~kg} \mathrm{ha}^{-1} \\
\text { Nitrogen } 50 \mathrm{~kg} \mathrm{ha}^{-1}\end{array}$ & $\begin{array}{l}\mathrm{P}_{45} \text {-at direct sowing } \\
\mathrm{N}_{50} \text {-at the tillering phase in early spring }\end{array}$ \\
\hline 7 & $\mathrm{P}_{45}+\mathrm{N}_{75}$ & $\begin{array}{l}\text { Phosphorous } 45 \mathrm{~kg} \mathrm{ha}^{-1} \\
\text { Nitrogen } 75 \mathrm{~kg} \mathrm{ha}^{-1}\end{array}$ & $\begin{array}{l}\mathrm{P}_{45} \text {-at direct sowing } \\
\mathrm{N}_{75} \text {-at the tillering phase in early spring }\end{array}$ \\
\hline 8 & $\mathrm{GS}+\mathrm{MNF}^{\dagger}$ & $\begin{array}{l}\text { Growth stimulant } 0.5 \mathrm{~L} / \mathrm{t}+\text { micronutrient fertilizer } \\
1 \mathrm{~L} / \mathrm{t} \text { Growth stimulant } 0.5 \mathrm{~L} / \mathrm{t}+\text { microfertilizer } 2 \mathrm{~L} / \mathrm{t}\end{array}$ & $\begin{array}{c}\text { One autumn treatment in the tillering phase Two } \\
\text { treatments: in early spring tillering and at flag } \\
\text { leaf phase. }\end{array}$ \\
\hline
\end{tabular}

${ }^{\dagger}$ In treatment 8 , the pre-sowing seed treatment was performed using a universal complex growth stimulant of contact-systemic action that consists of polyethylene oxide (PEO)- $770 \mathrm{~g} / \mathrm{L}$ and washed salts of humic acids-up to $30 \mathrm{~g} / \mathrm{L}$, and microfertilizer of the following content: $\mathrm{SO}_{3}-36 ; \mathrm{P}_{2} \mathrm{O}_{5}-66 ; \mathrm{K}_{2} \mathrm{O}-44 ; \mathrm{Zn}-8$; Fe-6; Cu-8; Co-0.05; B-6 g per litre. Fertilizers were applied on the depth of $10 \mathrm{~cm}$.

Plant density was determined on the test plots with a size of $0.25 \mathrm{~m}^{2}$, for each replication. Standing density was calculated in each phase. The content of dry matter was determined by grinding the green mass of the test grain with two weighed portions of $50 \mathrm{~g}$ each and dried at a temperature of $100-105^{\circ} \mathrm{C}$ to constant weight. The species composition of weeds and the load of weed infestation were determined according to [43]. In the last days of March, a mixture of the herbicides of a selective action were applied as a foliage spraying against annual and perennial dicotyledonous and grain weeds. The herbicides used were as follows: Ballerina is a systemic herbicide as a suspension emulsion against annual dicotyledons, including those resistant to 2,4-D and MCPA, and some perennial root weeds, contains: 2,4-D, complex 2-ethylhexyl; ether $410 \mathrm{~g} / \mathrm{L}$; florasulam 7.4 g/L. The Lastic extra is a selective herbicide for the control of annual cereal weeds containing antidote cloquintoset-mexil $40 \mathrm{~g}$ /L: fenoxaprop-P-ethyl $70 \mathrm{~g} / \mathrm{L}$. On 31 March, Ballerina 0.4 L/ha plus Lastic extra 100-0.9 L/ha herbicides were mixed with water separately and then the mixed solution was sprayed over the winter wheat plants in the amount of 200-300 L/ha. At the phase of the flag leaf before heading, the crops of the treatment number 8 were treated with a growth stimulant $0.5 \mathrm{~L} /$ ha plus micronutrient fertilizer $2.0 \mathrm{~L} / \mathrm{ha}$, in the evenings.

Direct sowing of winter wheat was performed with the Brazilian seeder FANKHAUSER 2115. The grain yield was determined for each plot by threshing with a Sampo-500 combine. All measurements were performed in four biological and analytical replicates.

Biometric characterization of plants consists of evaluating morphological properties of different parts of the plant, phenological phases such as start and duration of each stage of biological dvelopment of a plant, as well as seed chracteristics. The plant biometric parameters of winter wheat were determined according to the standard methods [44].

The economic efficiency of the technologies of direct sowing winter wheat with use of different doses of fertilizers was calculated based on technological maps at prices and rates in effect on average for 2019-2020. Statistical processing of the data obtained was carried out by the method of variance and correlation analysis [45]. The experimental results presented as mean values. A parametric assessment (one-way ANOVA) was performed at the probability level $(p) \leq 0.05$ to detect significant differences in the measured variables. 


\section{Results and Discussion}

The main soil agrochemical characteristics are given in Table 2. The studied soil is characterized by a low supply of nitrogen, phosphorus and good supply of potassium. The soil acidity level in the upper layer is weakly alkaline, and in the lower layers-alkaline. The humus content for this soil is usually low. Carbonates are present in all layers with a tendency to increase along the soil profile.

Table 2. Main agrochemical properties of the experimental field soil (2019).

\begin{tabular}{|c|c|c|c|c|c|c|c|c|}
\hline \multirow[b]{2}{*}{ Soil Layer, cm } & \multicolumn{4}{|c|}{ Total Content, \% } & \multirow[b]{2}{*}{$\mathrm{pH}$ in $\mathrm{H}_{2} \mathrm{O}$} & \multicolumn{3}{|c|}{ Mobile Nutrients, mg/100 g } \\
\hline & Humus & Nitrogen & $\mathrm{CO}_{2}$ & $\mathrm{CaCO}_{3}$ & & $\begin{array}{c}\text { Hydrolysable } \\
\text { N }\end{array}$ & $\mathrm{P}_{2} \mathrm{O}_{5}$ & $\mathrm{~K}_{2} \mathrm{O}$ \\
\hline $0-10$ & 1.36 & 0.08 & 4.8 & 10.8 & 7.35 & 13.3 & 2.7 & 406 \\
\hline $10-20$ & 1.18 & 0.07 & 4.9 & 11.0 & 7.41 & 10.8 & 2.7 & 439 \\
\hline $20-35$ & 0.5 & 0.05 & 6.9 & 15.8 & 7.47 & 6.5 & 1.6 & 308 \\
\hline $35-50$ & 0.3 & 0.05 & 8.7 & 19.7 & 8.50 & nd & 1.4 & 320 \\
\hline 50-100 & nd & nd & 9.0 & 20.5 & 8.50 & nd & nd & nd \\
\hline
\end{tabular}

Note: the data are the average of four field replications; nd-not determined

\subsection{Influence of Climatic Factors and Fertilizers on Germination and Wintering of Winter Wheat} in 2019 and 2020

3.1.1. Germination and Wintering of Winter Wheat in 2019

Generally, in 2019, the air temperature and amount of precipitation were favorable for obtaining simultaneous and uniform shooting of winter wheat (in October 2018, there was $44.2 \mathrm{~mm}$ rainfall) (Table S1). Full shoots were obtained on the 11th day with a high field germination rate of $87.8-94.7 \%$ (Table 3 ).

Table 3. Phenological phases of development of winter wheat with direct sowing depending on fertilization in South Kazakhstan (days after sowing).

\begin{tabular}{|c|c|c|c|c|c|c|c|c|c|c|c|}
\hline No. & Treatments & Year & $\begin{array}{c}\text { Sowing- } \\
\text { Germination }\end{array}$ & $\begin{array}{l}\text { Germination- } \\
\text { Tillering }\end{array}$ & $\begin{array}{l}\text { Tillering- } \\
\text { Booting }\end{array}$ & $\begin{array}{l}\text { Booting- } \\
\text { Earing }\end{array}$ & $\begin{array}{l}\text { Earing - } \\
\text { Flowering }\end{array}$ & $\begin{array}{l}\text { Flowering- } \\
\text { Milk } \\
\text { Maturity }\end{array}$ & $\begin{array}{c}\text { Milk- } \\
\text { Waxy } \\
\text { Maturity }\end{array}$ & $\begin{array}{c}\text { Waxy- } \\
\text { Full } \\
\text { Maturity }\end{array}$ & $\begin{array}{c}\text { Sowing-Full } \\
\text { Grain } \\
\text { Maturity }\end{array}$ \\
\hline \multirow{2}{*}{1} & \multirow{2}{*}{ control } & 2019 & 11 & 21 & 18 & 43 & 6 & 9 & 12 & 11 & 254 \\
\hline & & 2020 & 28 & 41 & 20 & 40 & 5 & 9 & 11 & 11 & 239 \\
\hline \multirow{2}{*}{2} & \multirow{2}{*}{$\mathrm{P}_{30}$} & 2019 & 11 & 20 & 17 & 40 & 6 & 8 & 11 & 10 & 249 \\
\hline & & 2020 & 28 & 40 & 19 & 38 & 5 & 8 & 10 & 11 & 235 \\
\hline \multirow{2}{*}{3} & \multirow{2}{*}{$\mathrm{P}_{45}$} & 2019 & 11 & 20 & 17 & 40 & 6 & 8 & 10 & 10 & 248 \\
\hline & & 2020 & 28 & 40 & 19 & 38 & 5 & 7 & 10 & 10 & 234 \\
\hline \multirow[b]{2}{*}{4} & \multirow[b]{2}{*}{$\mathrm{P}_{30} \mathrm{~N}_{50}$} & 2019 & 11 & 19 & 16 & 40 & 6 & 9 & 13 & 12 & 255 \\
\hline & & 2020 & 28 & 39 & 18 & 39 & 5 & 9 & 12 & 13 & 241 \\
\hline \multirow[b]{2}{*}{5} & \multirow{2}{*}{$\mathrm{P}_{30} \mathrm{~N}_{70}$} & 2019 & 11 & 19 & 16 & 41 & 6 & 9 & 13 & 12 & 256 \\
\hline & & 2020 & 28 & 39 & 18 & 40 & 5 & 9 & 12 & 13 & 242 \\
\hline \multirow[b]{2}{*}{6} & \multirow{2}{*}{$\mathrm{P}_{45} \mathrm{~N}_{50}$} & 2019 & 11 & 18 & 16 & 40 & 6 & 9 & 13 & 12 & 255 \\
\hline & & 2020 & 28 & 38 & 18 & 39 & 5 & 9 & 12 & 13 & 241 \\
\hline \multirow[b]{2}{*}{7} & \multirow{2}{*}{$\mathrm{P}_{45} \mathrm{~N}_{70}$} & 2019 & 11 & 18 & 16 & 41 & 6 & 9 & 13 & 12 & 257 \\
\hline & & 2020 & 28 & 38 & 18 & 40 & 5 & 9 & 12 & 13 & 243 \\
\hline \multirow{2}{*}{8} & \multirow{2}{*}{$\mathrm{GS}+\mathrm{MNF}^{\dagger}$} & 2019 & 11 & 18 & 16 & 39 & 6 & 8 & 12 & 11 & 243 \\
\hline & & 2020 & 28 & 38 & 18 & 38 & 5 & 8 & 11 & 10 & 234 \\
\hline
\end{tabular}

${ }^{\dagger}$ GS-growth stimulant; MNF-micronutrient fertilizer; at the beginning of the tillering phase the plants were treated with a GS $0.5 \mathrm{~L} /$ ha plus MNF $2.0 \mathrm{~L} / \mathrm{ha}$.

The very high rates of seeds' germination were apparently due to the good contact with the soil and their uniform embedding at a depth of $4-5 \mathrm{~cm}$. This was possible because in October there was a sufficient amount of precipitation with an optimal air temperature regime (Table S1), which ensured the intensive emergence of seedlings with a high field germination rate.

The condition of winter wheat plants before going into winter is crucial in obtaining high yields, since it determines cold resistance, growth, development and the course of crop formation [46]. In November, the temperature sharply dropped (from $12.3^{\circ} \mathrm{C}$ in October to $3.8^{\circ} \mathrm{C}$ in November) and the amount of precipitation increased from $44.2 \mathrm{~mm}$ in October to 
$85.3 \mathrm{~mm}$ in November (Table S1). Under the prevailing climatic conditions, winter wheat developed at a moderate pace and entered the tillering phase at the end of November 2019 (Table 3). In general, the state of the crops was good before going into winter and the autumn vegetation of plants continued.

On average, during the winter months in 2019, the total amount of atmospheric precipitation was $222.0 \mathrm{~mm}$, which is slightly lower than the long-term average (234.0 $\mathrm{mm}$ ). The average monthly air temperature fluctuated within 2.0 and $3.0^{\circ} \mathrm{C}$. In the winter precipitation mainly fell as a rain and wet snow with a shallow snow cover of $7-11 \mathrm{~cm}$, which rapidly thawed. The freezing of the soil was not observed and the plants of winter wheat overwintered safely.

The preserved plants in the fertilized treatments ranged from $261.8-310.6$ pieces $/ \mathrm{m}^{2}$ or $74.8-88.7 \%$ of the number of sown seeds (Table 4 ). According to the visual observations, some sparseness of plants was due to the damage of crops by birds, such as a sparrow and a crow. The number of preserved plants in the control treatment was $238.0 \mathrm{pcs} \mathrm{m}^{-2}$, which is significantly lower than in the fertilized variants. From these results, it follows that the simultaneous application of phosphorus fertilizers alone as well as the combinations of phosphorus and nitrogen fertilizers with the direct sowing of winter wheat contributed to an increase in the cold resistance of plants and their safety from unfavorable winter conditions.

Table 4. Biometric indicators of the rainfed winter wheat development with direct sowing and various fertilization in South Kazakhstan.

\begin{tabular}{|c|c|c|c|c|c|c|c|c|c|c|c|c|c|}
\hline \multirow[t]{2}{*}{ No. } & \multirow[t]{2}{*}{ Treatment } & \multicolumn{2}{|c|}{$\begin{array}{c}\text { Number of } \\
\text { Overwintered } \\
\text { Plants, pcs } \mathrm{m}^{-2}\end{array}$} & \multicolumn{2}{|c|}{$\begin{array}{l}\text { Ear Quantity, } \\
\text { pcs m }{ }^{-2}\end{array}$} & \multicolumn{2}{|c|}{ Plant Height, cm } & \multicolumn{2}{|c|}{ Ear Length, cm } & \multicolumn{2}{|c|}{$\begin{array}{c}\text { Number of } \\
\text { Grains per Ear, } \\
\text { pcs }\end{array}$} & \multicolumn{2}{|c|}{$\begin{array}{l}\text { Weight of } 1000 \\
\text { Seeds }\end{array}$} \\
\hline & & 2019 & 2020 & 2019 & 2020 & 2019 & 2020 & 2019 & 2020 & 2019 & 2020 & 2019 & 2020 \\
\hline 1 & control & $\underset{+}{238.0} \mathrm{a}$ & 243.4 a & $202.3 a$ & $207.0 \mathrm{a}$ & $68.5 \mathrm{a}$ & $73.6 \mathrm{a}$ & $7.0 \mathrm{a}$ & $6.8 \mathrm{a}$ & $20.0 \mathrm{a}$ & $21.1 \mathrm{a}$ & $30.6 a$ & $13.2 \mathrm{a}$ \\
\hline 2 & $\mathrm{P}_{30}$ & $261.6 \mathrm{~b}$ & $270.3 b$ & $212.1 \mathrm{a}$ & $217.2 \mathrm{~b}$ & $78.5 \mathrm{~b}$ & $80.1 \mathrm{~b}$ & $8.6 b$ & $8.9 \mathrm{~b}$ & $25.1 \mathrm{~b}$ & $23.9 \mathrm{a}$ & $35.0 \mathrm{~b}$ & $17.5 \mathrm{~b}$ \\
\hline 3 & $\mathrm{P}_{45}$ & $269.7 b$ & $272.0 \mathrm{~b}$ & $215.8 \mathrm{a}$ & $220.1 b$ & $80.2 \mathrm{~b}$ & $81.3 \mathrm{~b}$ & $8.7 \mathrm{~b}$ & $8.8 \mathrm{~b}$ & $26.0 \mathrm{~b}$ & 25.3ab & $35.7 \mathrm{~b}$ & $19.1 b$ \\
\hline 4 & $\mathrm{P}_{30} \mathrm{~N}_{50}$ & $271.5 b$ & $295.6 c$ & $265.4 b$ & $271.3 c$ & $88.1 \mathrm{bc}$ & $90.4 \mathrm{bc}$ & $9.9 \mathrm{c}$ & $9.6 \mathrm{bc}$ & $32.4 \mathrm{c}$ & $31.7 \mathrm{~b}$ & $37.1 \mathrm{bc}$ & $31.7 \mathrm{c}$ \\
\hline 5 & $\mathrm{P}_{30} \mathrm{~N}_{70}$ & $288.9 \mathrm{c}$ & $303.8 \mathrm{c}$ & $281.1 b c$ & $283.2 c$ & $89.7 \mathrm{bc}$ & $92.1 \mathrm{bc}$ & $10.2 \mathrm{c}$ & $9.8 \mathrm{c}$ & $33.2 \mathrm{c}$ & $32.6 b$ & $37.3 b c$ & $34.3 \mathrm{c}$ \\
\hline 6 & $\mathrm{P}_{45} \mathrm{~N}_{50}$ & $295.5 c$ & $318.6 \mathrm{~cd}$ & $290.0 c$ & $300.1 \mathrm{~cd}$ & $94.9 \mathrm{c}$ & $93.4 b c$ & $10.8 \mathrm{c}$ & $10.9 \mathrm{c}$ & $33.4 \mathrm{c}$ & $32.0 \mathrm{~b}$ & $37.0 \mathrm{bc}$ & $35.4 \mathrm{c}$ \\
\hline 7 & $\mathrm{P}_{45} \mathrm{~N}_{70}$ & $310.6 \mathrm{~cd}$ & $325.8 \mathrm{~d}$ & $302.2 \mathrm{c}$ & $302.0 \mathrm{~cd}$ & $95.8 \mathrm{c}$ & $98.4 \mathrm{~b}$ & $10.9 c$ & $11.2 \mathrm{c}$ & $34.0 \mathrm{c}$ & $32.8 b$ & $37.5 \mathrm{bc}$ & $36.8 \mathrm{~cd}$ \\
\hline 8 & $\mathrm{GS}+\mathrm{MNF}^{++}$ & $269.5 b$ & $288.6 \mathrm{e}$ & $245.0 \mathrm{~d}$ & $269.0 \mathrm{c}$ & $79.8 \mathrm{~b}$ & $84.5 \mathrm{~b}$ & $8.5 b$ & $9.3 \mathrm{bc}$ & $28.1 \mathrm{bc}$ & $29.8 b$ & $35.1 \mathrm{~b}$ & $27.7 \mathrm{c}$ \\
\hline
\end{tabular}

${ }^{\dagger}$ The different letters within a column indicate a statistically significant difference at $p<0.05 ;{ }^{+\dagger}$ GS-growth stimulant; MNF-micronutrient fertilizer.

\subsubsection{Germination and Wintering of Winter Wheat in 2020}

In 2019, at the time of wheat sowing in October, the high air temperature and the absence of precipitation (10 $\mathrm{mm}$ in October) created an autumn drought. Despite unfavorable conditions for field work, the direct sowing of winter wheat to a depth of 4-5 cm with simultaneous application of phosphorus fertilizers at the rate of $P_{30}$ and $P_{45} \mathrm{~kg} / \mathrm{ha}$ was carried out on October 19.

In the first 10 days of November, the air temperature became cooler $\left(7.0^{\circ} \mathrm{C}\right)$ and the amount of precipitation less $(12.1 \mathrm{~mm})$, compared to the mean annual climatic conditions. This amount of precipitation was just enough to moisten the soil surface to the depth of direct planting seeds and for the formation of primary roots. However, for the emergence of seedlings, the moisture reserve was insufficient; therefore, until November 18, the seedlings of winter wheat did not appear. Although subsequent rainfall encouraged wheat germination, negative temperatures resulted in only scattered seedlings emerging.

From the beginning of December, warm rain fell in the amount of $88.1 \mathrm{~mm}$ and the average 10-day air temperature increased $\left(+3.1^{\circ} \mathrm{C}\right.$ that is 1.2 times more than long-term norm). This resulted in full shoots of winter wheat appearing at the beginning of December and the vegetation lasting until the end of December. It should be noted that in the South Kazakhstan, the continuation of the growing winter cereals in winter is a common phenomenon. In January 2020, the wet snow precipitation amounted to $81.7 \mathrm{~mm}$, or for $10.7 \mathrm{~mm}$ higher than normal. The snow quickly thawed and penetrated into the deeper 
soil layers. The average monthly air temperature was $-0.1^{\circ} \mathrm{C}$, so soil freezing was not observed. In January, winter wheat suspended the growing until the end of the month.

Basically, in both years of no-till, the plants overwintered successfully and created a good foundation for high grain yields. Likewise, [47], comparing the effects of no till and shallow till on winter wheat in the arid steppes of Russia, found that with no till, plants were better prepared for wintering and better preserved after winter, which ultimately resulted in increasing the crop yield. This was mainly due to better soil water-physical and agrochemical characteristics in a no-till system.

\subsection{Influence of Climatic Factors and Fertilizers on the Growth and Development of Winter Wheat} in 2019 and 2020

From the beginning of March 2019, the weather was warm with the average monthly air temperature $10.8{ }^{\circ} \mathrm{C}$ that is $1.6^{\circ} \mathrm{C}$ above the norm, and $30.1 \mathrm{~mm}$ precipitation, which was 2.7 times lower than the multi-year norm. However, the total amount of autumnwinter precipitation $(351.5 \mathrm{~mm})$ penetrated to the soil depth thereby creating satisfactory reserves of productive moisture in the soil of $176 \mathrm{~mm}$ in a meter layer. This moisture reserve supported an intensive development of winter wheat. Moreover, on the treatments where nitrogen fertilization $\left(\mathrm{N}_{30}\right.$ and $\left.\mathrm{N}_{45} \mathrm{~kg} / \mathrm{ha}\right)$ and the spring treatment of crops with the growth stimulant $0.5 \mathrm{~L} /$ ha plus micronutrient fertilizers $2.0 \mathrm{~L} /$ ha were applied, the plants developed rapidly and intensely.

In April 2019, the amount of precipitation was $138.4 \mathrm{~mm}$, which was two times more than the multi-year norm. This contributed to the accumulation of soil productive moisture of $191 \mathrm{~mm}$ in a $0-100 \mathrm{~cm}$ soil depth (Table 5). The high temperatures in the first and second 10 days contributed to the intensive development of winter wheat with their transition to the booting phase and growth in height.

Table 5. Accumulated moisture reserves under winter wheat at various phases of the plant vegetation (2019 and 2020).

\begin{tabular}{ccccc}
\hline & \multicolumn{4}{c}{ Moisture Reserve $\mathbf{( m m})$ in Soil Layers $\mathbf{( c m )}$} \\
Sampling Date & $\mathbf{0 - 1 0}$ & $\mathbf{0 - 2 0}$ & $\mathbf{0 - 5 0}$ & $\mathbf{0 - 1 0 0}$ \\
\hline 08 March 2019 & 11 & 28 & 82 & 176.0 \\
18 March 2019 & 10 & 23 & 71 & 169.5 \\
28 March 2019 & 15 & 34 & 76 & 176.0 \\
08 April 2019 & 20 & 41 & 98 & 191.0 \\
18 April 2019 & 20 & 40 & 96 & 182.0 \\
28 April 2019 & 23 & 47 & 98 & 196.0 \\
08 May 2019 & 10 & 22 & 63 & 152.0 \\
18 May 2019 & 11 & 30 & 58 & 143.0 \\
28 May 2019 & 10 & 49 & 45 & 94.0 \\
08 March 2020 & 25 & 45 & 102 & 173.0 \\
18 March 2020 & 23 & 46 & 100 & 166.0 \\
28 March 2020 & 21 & 44 & 110 & 207.7 \\
08 April 2020 & 21 & 24 & 108 & 205.2 \\
18 April 2020 & 11 & 20 & 68 & 160.1 \\
28 April 2020 & 9 & 24 & 59 & 150.7 \\
08 May 2020 & 11 & 12 & 61 & 146.4 \\
18 May 2020 & 5 & 6 & 43 & 170.0 \\
28 May 2020 & 2 & & 29 & 84.0 \\
\hline
\end{tabular}

From the beginning of May 2019, air temperatures were higher than normal, and the amount of precipitation was 2.4 times lower than normal. Therefore, by the end of May, the reserves of productive soil moisture decreased to $94 \mathrm{~mm}$ in the $0-100$ depth.

From the beginning of February, the daily temperature has increased and overall, $103.5 \mathrm{~mm}$ of precipitation fell resulting in a resumption of the vegetation of winter wheat. The average monthly air temperature was 4.7 times higher than the norm, which con- 
tributed to the continuation of the vegetation of winter wheat plants with their transition to the tillering phase.

In March, air temperatures increased substantially (1.3 and 2.1 times higher than the multi-year norm in the first and second 10 days), resulting in greater evaporation of soil moisture. However, lack of precipitation was compensated by the previously accumulated soil productive moisture $173 \mathrm{~mm}$ (8 March 2020) and $166 \mathrm{~mm}$ (18 March 2020) (Table 5). This allowed winter wheat to develop intensively and enter in the tillering phase. However, at the same time, ideal conditions were also formed for the emergence and intensive growth weeds. Therefore, at the beginning of the vegetation, the plants were treated with a mixture of the herbicides. The biological effectiveness of systemic herbicides ranged from 85.9 to $94.7 \%$.

From the beginning of April 2020, there have been favorable conditions for plant growth (the amount of precipitation was $32.9 \mathrm{~mm}$ higher than the mean annual). From 8 April, the plants in the fertilized treatments developed rapidly with the transition to the booting phase, except in the control, where the plants lagged behind both in growth and development.

In the first and second 10 days of May the amount of precipitation was by 3.2 times higher than the perennial average, which provided a good supply of productive moisture in a meter layer of soil $(170 \mathrm{~mm})$. However, because the temperature sharply increased and no precipitation occurred at the third 10 day period in May, plants entered the heading phase followed by flowering. It should be noted that the cultivated variety "Steklovidnaya-24" under high thermal conditions (during the day the temperature recorded above $40^{\circ} \mathrm{C}$ ) and at low relative air humidity $(17 \%)$, successfully developed uniform grain formation. This implies that the variety is resistant to the dry and hot weather of South Kazakhstan. By the end of May (28 May 2020), the reserves of productive moisture in the 0-100 layer dropped to $84 \mathrm{~mm}$ or in 10 days, it decreased by 1.6 times. This is explained by higher air temperatures and a greater demand for water of winter wheat in this biological phase of plant development [48].

In general, during both years, no tillage and direct sowing managed to accumulate moisture reserves in the soil at levels capable of ensuring good growth and development of winter wheat plants. This is explained by the fact that under direct sowing and absence of ploughing the moisture accumulated in the soil is less prone to evaporation due to the protective mulching layer on the soil surface, thus effectively accumulating and storing productive moisture reserves [49].

\subsection{Influence of Climatic Factors and Fertilizers on the Productive Parameters of Winter Wheat in} 2019 and 2020

The results show that the application of phosphorus fertilizers at the rates of P30 and $\mathrm{P}_{45} \mathrm{~kg} / \mathrm{ha}$ accelerated grain ripening by 5-6 days compared to the control (Table 3). The use of phosphorus and nitrogen fertilizers at the rates of $\mathrm{P}_{45} \mathrm{~N}_{70} \mathrm{~kg} / \mathrm{ha}$ extended the length of the growing season of winter wheat up to 257 days, with maturation of winter wheat grain occurred 4 days later compared to the control (253 days) and 9 days later compared to the $\mathrm{P}_{45} \mathrm{~kg} / \mathrm{ha}$ (248 days) (Table 3). When using plant growth stimulants with micronutrient fertilizer, the length of the growing season was 247 days implying that this amendment accelerated the processes of grain ripening by 6 days in comparison with the control (Table 3). During the milky and waxy maturity of grain in 2020, the weather was generally very hot and dry, which accelerated the maturation of winter wheat grains.

Nevertheless, on fertilized treatments, the efficient use of productive moisture reserves on rainfed lands led to a high yield of winter wheat. The yield of winter wheat in rainfed conditions was largely determined by the productive tillering and the number of plants per unit area. In the 2019-2020 years, the number of plants per unit area increased from 212.1 to $302.2 \mathrm{pcs} \mathrm{m}^{-2}$ in 2019 and from 217.2 to $302.0 \mathrm{pcs} \mathrm{m}^{-2}$ in 2020 in the fertilized treatments against the control (202.3 and $207.0 \mathrm{pcs} / \mathrm{m}^{2}$ in 2019 and 2020 years, respectively) (Table 4). 
One of the indicators determining the yield of grain crops is the number of grains per ear, the length of the ear, the number of grains per ear and the weight of 1000 grains. The lowest number of grains per spike was in the control (the number of grains per spike was 20.0-21.1 pcs). Use of fertilizers and improved nutritional conditions increased the number of grains and their length. The largest number $(32.8-34.0 \mathrm{pcs})$ and length $(10.9-11.2 \mathrm{~cm})$ were obtained with application of phosphorus fertilizers at direct sowing in the dose of $\mathrm{P}_{45}$ $\mathrm{kg} / \mathrm{ha}$ and with nitrogen added in the tillering phase early spring in a dose of $\mathrm{N}_{70} \mathrm{~kg} / \mathrm{ha}$ (Table 4). Use of the growth stimulants and micronutrients resulted in the number of grains in an ear of 28.1-29.8 pcs and the length of an ear of 9.5-9.3 cm.

In June of both years, high air temperatures, little precipitation and low relative air humidity (Table S1) accelerated grain ripening and 1000 seeds weight (Table 4). The largest weight of 37.5-37.2 g was obtained under use of $P_{45} \mathrm{~N}_{70} \mathrm{~kg} / \mathrm{ha}$, compared to the control (30.6-30.3 g).

Obviously, for the uniform course of development of winter wheat and the formation of stable productivity parameters, in the rainfed conditions with direct sowing, the decisive factor was the optimization of nutritional conditions with consideration of the biological needs of plant and appropriate pest control.

\subsection{Impact of Fertilizer on Grain Yield of Rainfed Winter Wheat for 2019-2020}

Our results confirm that the effectiveness of the applied fertilizers depends on the moisture level, the amount of precipitation in the field and the time of precipitation during the growing season of winter wheat. Higher precipitation in October and November 2018 allowed for better dissolution of the applied phosphorus and positively influenced the growth and deep root setting of winter wheat [35,48]. Normally, after the appearance of the first shoots, in the presence of a sufficient amount of moisture in the soil, the roots of winter wheat grow to the sides and an intensive deep growth occurs along the soil [48]. In our case, winter precipitation saturated the soil for 2-3 days, as a result of which 176 $\mathrm{mm}$ of moisture accumulated at a depth of $0-100 \mathrm{~cm}$ in the first days of spring, which is an excellent amount of moisture for an arid climate.

The application of phosphorus fertilizers at the rate of $\mathrm{P}_{30} \mathrm{nP}_{45} \mathrm{~kg} / \mathrm{ha}$ at the time of direct sowing, increased the grain yield of wheat by 0.48 and $0.68 \mathrm{t} / \mathrm{ha}$, respectively, compared with the control (Table 6). These results are important because generally, in arid climate with alkaline soil $\mathrm{pH}$, phosphorus availability is restricted due to precipitation reactions and/or fixation by calcium carbonate and clay minerals [50] and become unavailable to plants. Despite the phosphorus fertilizers being applied during the autumn drought, the plants were able to effectively use phosphorus due to the moisture reserves accumulated in sufficient quantities because of reduced evaporation due to the mulch layer.

Table 6. Grain yield of rainfed winter wheat at direct sowing as affected by doses of mineral fertilization in South Kazakhstan (average for four field replications).

\begin{tabular}{cccccc}
\hline No. & Treatment & \multicolumn{2}{c}{ Grain Yield, $\mathbf{t} / \mathbf{h a}$} & $\begin{array}{c}\text { Average Grain } \\
\text { Yield, } \mathbf{t} / \mathbf{h a}\end{array}$ & $\begin{array}{c}\text { Deviation from } \\
\text { Control, } \mathbf{t} / \mathbf{h a}\end{array}$ \\
\cline { 3 - 4 } & $\mathbf{2 0 1 9}$ & $\mathbf{2 0 2 0}$ & & - \\
\hline 1 & control & $1.24 \mathrm{a} \mathrm{a}^{\dagger}$ & $1.32 \mathrm{a}$ & $1.28 \mathrm{a}$ & +0.48 \\
2 & $\mathrm{P}_{30}$ & $1.80 \mathrm{~b}$ & $1.75 \mathrm{a}$ & $1.76 \mathrm{~b}$ & +0.68 \\
3 & $\mathrm{P}_{45}$ & $2.01 \mathrm{~b}$ & $1.91 \mathrm{ab}$ & $1.96 \mathrm{~b}$ & +1.90 \\
4 & $\mathrm{P}_{30} \mathrm{~N}_{50}$ & $3.19 \mathrm{c}$ & $3.17 \mathrm{c}$ & $3.18 \mathrm{c}$ & +2.18 \\
5 & $\mathrm{P}_{30} \mathrm{~N}_{70}$ & $3.48 \mathrm{c}$ & $3.43 \mathrm{c}$ & $3.46 \mathrm{c}$ & +2.28 \\
6 & $\mathrm{P}_{45} \mathrm{~N}_{50}$ & $3.58 \mathrm{c}$ & $3.54 \mathrm{c}$ & $3.56 \mathrm{c}$ & +2.49 \\
7 & $\mathrm{P}_{45} \mathrm{~N}_{70}$ & $3.85 \mathrm{~cd}$ & $3.68 \mathrm{c}$ & $3.77 \mathrm{c}$ & +1.31 \\
\hline & $\mathrm{GS}+\mathrm{MNF}$ & $2.42 \mathrm{bc}$ & $2.77 \mathrm{bc}$ & $2.59 \mathrm{bc}$ & \\
\hline
\end{tabular}

${ }^{\dagger}$ The different letters within a column indicate a statistically significant difference; ${ }^{+\dagger}$ GS: growth stimulant; MNF: micronutrient fertilizer. 
Application of phosphorus (P30 kg/ha) in combination with nitrogen $\left(\mathrm{N}_{50}\right.$ and $\mathrm{N}_{70}$ $\mathrm{kg} / \mathrm{ha}$ ) contributed to the increase in grain yield by $1.90-2.18 \mathrm{t} / \mathrm{ha}$ compared to the control, producing high grain yield per hectare between 3.18 and $3.46 \mathrm{t} / \mathrm{ha}$. This suggests that the use of phosphorus-nitrogen fertilizers in a proposed dosage and timing contributed to the balanced nutritional regime during the entire growing season and thereby providing a high grain yield. This assumption is supported by the highest grain yield of $3.77 \mathrm{t} / \mathrm{ha}$ on average over two years, formed on the treatment with application of phosphorus fertilizers at the rate of $\mathrm{P}_{45} \mathrm{~kg} / \mathrm{ha}$ at the direct sowing and nitrogen fertilizer at the rate of $\mathrm{N}_{70} \mathrm{~kg} / \mathrm{ha}$ in early spring in the tillering phase (Table 6). In this treatment, the grain yield was 2.9 times higher than in the control. Optimization of the phosphate and nitrogen nutritional regimes of winter wheat during the period of their greatest need balanced the plant nutrition. Probably, the synergetic phenomenon took an action, i.e., optimization of one factor of biological cycle enhanced the action of other factors [51]. Earlier studies also showed that minimization of soil mechanical disturbance facilitates optimization of crop nutrition and soil moisture [52] as well as reduces the cost of resources [35,52,53].

\subsection{Economic Assessment of the Direct Sowing of Winter Wheat in Southern Kazakhstan}

The current financial difficulties of farms and the lack of the necessary equipment and processing facilities have made it practically impossible to maintain the existing farming system at a sustainable level. Therefore, the development of economically and energy efficient agricultural technologies in accordance with the local climate and soil is a priority for grain production in South Kazakhstan.

The cost of 1 tonne of product and the percentage of economic efficiency were calculated by taking into account the total cost of the product from 1 hectare of land and the net profit of the product for each treatment for the yield of 2019 and 2020 (Table 7). Economic calculations included the cost of agro-technical measures used in the experimental fields, the cost of herbicides and fertilizers and fuels and lubricants, as well as the cost of labor and equipment for their application into the field. In 2019, the cost per hectare varied depending on the cost of sown seeds, cost of phosphorus and nitrogen fertilizers and micronutrients, as well as on the cost of plant growth stimulants and herbicides used. The cost of the cultivation winter wheat without fertilizers (control) amounted to about EUR 44 per hectare and the cost of the fertilized treatments increased in line with the amounts of fertilizer applied reaching around EUR 112 in the treatment number $7\left(\mathrm{P}_{45} \mathrm{~N}_{70}\right)$ and around EUR 61 in number 8 (Table 7). However, the trend of the net profit per hectare was oppositely distributed with the lowest profit around EUR 131 in the control and around EUR 432 in treatment number $7\left(\mathrm{P}_{45} \mathrm{~N}_{70}\right)$ and EUR 281 in treatment number 8.

In today's market conditions, the price of fuel and lubricants used in the agricultural system is at its peak; therefore, the cost of products per one tonne in the fertilized fields is much higher than the non-fertilized one. But the conditional net profit per hectare in fertilized treatments is multiplied. The highest cost of production of 1 tonne of winter wheat grain was in the control plots that did not receive any amendments, and the lowest cost was in treatment number 8 with addition of plant growth stimulants together with micronutrient fertilizer. Treatments of winter wheat seeds with the growth stimulant and micronutrients doubled the grain yield $(2.59 \mathrm{t} / \mathrm{ha})$ compared with the control and at the same time nearly for two times reduced the cost of 1 tonne of grain (Table 7). So, the use of plant growth regulators proved to be profitable for farmers and a completely justified agro-technological method for direct sowing of winter wheat with a significant reduction in direct costs of their cultivation.

The above discussed results confirm the earlier findings on the economic efficiency of zero-till technology of cultivation of cereals on dry areas of South Kazakhstan [53,54]. The later researchers found that the cost of production of winter wheat with direct sowing decreased by $30.2 \%$, fuel costs decreased by $38.6 \%$, and net profit increased by $16.7 \%$ on average, compared with the traditional agro-technological system $[53,54]$. 
Table 7. Economic efficiency of fertilizers used in the cultivation of winter wheat with "zero" technology in 2019 and 2020.

\begin{tabular}{|c|c|c|c|c|c|c|c|c|c|c|c|c|}
\hline \multirow{3}{*}{ Treatment } & \multicolumn{2}{|c|}{ Grain Yield } & \multicolumn{2}{|c|}{$\begin{array}{l}\text { Production } \\
\text { Costper } 1 \text { ha }\end{array}$} & \multicolumn{2}{|c|}{$\begin{array}{l}\text { Price of Grain } \\
\text { Produced }\end{array}$} & \multirow{2}{*}{\multicolumn{2}{|c|}{$\begin{array}{c}\begin{array}{c}\text { Net Profit per } \\
\text { Hectare }\end{array} \\
\text { KZT }^{*} \\
\end{array}$}} & \multicolumn{2}{|c|}{$\begin{array}{c}\text { Cost of } 1 \text { Ton } \\
\text { of Product }\end{array}$} & \multirow{2}{*}{\multicolumn{2}{|c|}{$\begin{array}{c}\begin{array}{c}\text { Cost of } 1 \text { Ton } \\
\text { of Product }\end{array} \\
\text { EUR }\end{array}$}} \\
\hline & \multicolumn{4}{|c|}{ t/ha } & & & & & & & & \\
\hline & 2019 & 2020 & 2019 & 2020 & 2019 & 2020 & 2019 & 2020 & 2019 & 2020 & 2019 & 2020 \\
\hline control & 1.24 & 1.32 & 21,800 & 26,300 & 86,800 & 118,800 & 65,000 & 92,500 & 17,580 & 19,920 & 35,472 & 40,194 \\
\hline $\mathrm{P}_{30}$ & 1.86 & 1.75 & 30,600 & 38,500 & 130,200 & 157,800 & 99,600 & 119,300 & 16,450 & 22,000 & 33,192 & 44,391 \\
\hline $\mathrm{P}_{45}$ & 2.01 & 1.91 & 35,000 & 44,700 & 140,700 & 171,900 & 105,700 & 127,200 & 17,410 & 23,400 & 35,129 & 47,215 \\
\hline$P_{30} N_{50}$ & 3.19 & 3.17 & 45,100 & 54,800 & 223,300 & 285,300 & 178,200 & 230,500 & 14,130 & 17,280 & 28,511 & 34,867 \\
\hline $\mathrm{P}_{30} \mathrm{~N}_{70}$ & 3.48 & 3.43 & 50,900 & 61,300 & 243,600 & 308,700 & 192,700 & 247,400 & 14,620 & 17,870 & 29,500 & 36,057 \\
\hline $\mathrm{P}_{45} \mathrm{~N}_{50}$ & 3.58 & 3.54 & 49,600 & 60,900 & 250,600 & 318,600 & 201,000 & 257,700 & 13,850 & 17,200 & 27,946 & 34,705 \\
\hline $\mathrm{P}_{45} \mathrm{~N}_{70}$ & 3.85 & 3.68 & 55,400 & 67,400 & 269,500 & 331,200 & 214,100 & 263,800 & 14,390 & 18,320 & 29,036 & 36,965 \\
\hline $\mathrm{GS}+\mathrm{MNF}^{* *}$ & 2.42 & 2.77 & 30,200 & 30,200 & 169,400 & 249,300 & 139,200 & 219,100 & 12,470 & 10,900 & 25,161 & 21,994 \\
\hline
\end{tabular}

* KZT: Kazakhstan tenge, calculated at 1 euro (EUR) equal to 497.3 tenge (average on 02 November 2021). The average market price of 1 tonne of winter wheat grain in 2019 and 2020 was KZT 70,000 and 90,000, respectively; ** GS: growth stimulant; MNF: Micronutrient fertilizer.

\section{Conclusions}

The results have shown that in dry and hot climate conditions with a deficit moisture regime, direct sowing of rainfed winter wheat can be successfully applied provided an appropriate combination, dosage and timing of fertilizers and crop protection chemicals are applied.

Production of winter wheat grain with direct sowing and use of growth stimulants and macro and micronutrients has proven to be economically profitable compared to the control treatment.

Supplementary Materials: The following are available online at https:/ /www.mdpi.com/article/10 .3390/agronomy12010111/s1, Table S1: Average precipitation, air temperature and humidity for the years of observation, Shymkent, South Kazakhstan.

Author Contributions: Conceptualization, E.S.; Data curation, A.Z. and A.B.; Formal analysis, S.T. and A.Y.; Funding acquisition, S.T.; Investigation, K.A. and A.B.; Methodology, S.T.; Project administration, A.Y.; Resources, S.T.; Software, E.S.; Supervision, A.Z. and E.S.; Validation, A.Z. and G.Y.; Writing-review \& editing, E.S. All authors have read and agreed to the published version of the manuscript.

Funding: The Ministarstvo Prosvete, Naukei Tehnološkog Razvoja of the Republic of Serbia, grant number 451-03-09/2021-14/200011.

Conflicts of Interest: The authors declare no conflict of interest. The funders had no role in the design of the study; in the collection, analyses, or interpretation of data; in the writing of the manuscript, or in the decision to publish the results.

\section{References}

1. Koković, N.; Saljnikov, E.; Eulenstein, F.; Čakmak, D.; Buntić, A.; Sikirić, B.; Ugrenović, V. Changes in Soil Labile Organic Matter as Affected by 50 Years of Fertilization with Increasing Amounts of Nitrogen. Agronomy 2021, 11, 2026. [CrossRef]

2. Perović, V.; Kadović, R.; Đurđević, V.; Pavlović, D.; Pavlović, M.; Čakmak, D.; Mitrović, M.; Pavlović, P. Major drivers of land degradation risk in Western Serbia: Current trends and future scenarios. Ecol. Indic. 2021, 123, 107377. [CrossRef]

3. Duttmann, R.; Augustin, K.; Brunotte, J.; Kuhwald, M. Modeling of field traffic intensity and soil compaction risks in agricultural landscapes. In Advances in Understanding Soil Degradation; Saljnikov, E., Mueller, L., Lavrishchev, A., Eulenstein, F., Eds.; Springer: Cham, Switzerland, 2021; Chapter 14; ISSN 978-3-030-85681-6.

4. Mamontov, V.G. Classification and causes of soil degradation by irrigation in Russian steppe agrolandscapes. In Advances in Understanding Soil Degradation; Saljnikov, E., Mueller, L., Lavrishchev, A., Eulenstein, F., Eds.; Springer: Cham, Switzerland, 2021; Chapter 14; ISSN 978-3-030-85681-6. 
5. Saljnikov, E.; Eulenstein, F.; Lavrishchev, A.; Mirschel, W.; Blum, W.E.H.; McKenzie, B.M.; Lilburne, L.; Römbke, J.; Wilke, B.-M.; Schindler, U.; et al. Understanding Soils: Their Functions, Use and Degradation. In Advances in Understanding Soil Degradation; Saljnikov, E., Mueller, L., Lavrishchev, A., Eulenstein, F., Eds.; Springer: Cham, Switzerland, 2021; Chapter 1; ISSN 978-3-030-85681-6.

6. Saljnikov, E.; Mirschel, W.; Prasuhn, V.; Keller, T.; Blum, W.E.H.; Chumbaev, A.S.; Zhang, J.; Abuduwaili, J.; Eulenstein, F.; Lavrishchev, A.; et al. Types of Physical Soil Degradation and Implications for their Prevention and Monitoring. In Advances in Understanding Soil Degradation; Saljnikov, E., Mueller, L., Lavrishchev, A., Eulenstein, F., Eds.; Springer: Cham, Switzerland, 2021; Chapter 3; ISSN 978-3-030-85681-6.

7. Saljnikov, E.; Lavrishchev, A.; Römbke, J.; Rinklebe, J.; Scherber, C.; Wilke, B.-M.; Tóth, T.; Blum, W.E.H.; Behrendt, U.; Eulenstein, F.; et al. Understanding and Monitoring Chemical and Biological Soil Degradation. In Advances in Understanding Soil Degradation; Saljnikov, E., Mueller, L., Lavrishchev, A., Eulenstein, F., Eds.; Springer: Cham, Switzerland, 2021; Chapter 3; ISSN 978-3-03085681-6.

8. Larney, F.J.; Janzen, H.H.; Smith, E.G.; Anderson, D.W. Dryland Agriculture on the Canadian Prairies: Current Issues and Future Challenges. Chall. Strateg. Dryland Agric. 2004, 32, 113-138.

9. Malobane, M.E.; Nciizah, A.D.; Mudau, F.N.; Wakindiki, I.I. Tillage, crop rotation and crop residue management effects on nutrient availability in a sweet sorghum-based cropping system in marginal soils of South Africa. Agronomy 2020, 10, 776. [CrossRef]

10. Komissarov, M.A.; Klik, A. The Impact of No-Till, Conservation, and Conventional Tillage Systems on Erosion and Soil Properties in Lower Austria. Eur. Soil Sci. 2020, 53, 503-511. [CrossRef]

11. Jat, H.S.; Datta, A.; Choudhary, M.; Yadav, A.K.; Choudhary, V.; Sharma, P.C.; Gathala, M.K.; Jat, M.L.; McDonald, A. Effects of tillage, crop establishment and diversification on soil organic carbon, aggregation, aggregate associated carbon and productivity in cereal systems of semi-arid Northwest India. Soil Tillage Res. 2019, 190, 128-138. [CrossRef]

12. Keller, T.; Lamandé, M.; Naderi-Boldaji, M.; de Lima, R.P. Soil compaction due to agricultural field traffic: An overview of current knowledge and techniques for compaction quantification and mapping. In Advances in Understanding Soil Degradation; Saljnikov, E., Mueller, L., Lavrishchev, A., Eulenstein, F., Eds.; Springer: Cham, Switzerland, 2021; ISSN 978-3-030-85681-6.

13. Zhang, J.; Wamg, Y.; Zhang, Z.; Xu, H.; Dai, J. Tillage erosion accelerates water erosion in a hilly landscape. In Advances in Understanding Soil Degradation; Saljnikov, E., Mueller, L., Lavrishchev, A., Eulenstein, F., Eds.; Springer: Cham, Switzerland, 2021; ISSN 978-3-030-85681-6.

14. Larney, F.; Janzen, H.; Smith, E. Dryland Agriculture on the Canadian Prairies: Current Issues and Strategies for Dryland Agriculture. In Challenges and Strategies for Dryland Agriculture; Crop Science Society of America and American Society of Agronomy: Madison, WI, USA, 2004; pp. 113-138.

15. Suleimenov, M.K. Fundamentals of a Resource-Saving Farming System in Northern Kazakhstan-Crop Rotation and Zero or Minimal Tillage; Agrarian sector of Kazakhstan: Astana-Shortandy, Kazakhstan, 2011; pp. 16-27.

16. Cook, R.L.; Trlica, A. Tillage and fertilizer effects on crop yield and soil properties over 45 years in Southern Illinois. Agron. J. 2016, 108, 415-426. [CrossRef]

17. Lal, R. Researchable priorities in terrestrial carbon sequestration in Central Asia. In Climate Change and Terrestrial Carbon Sequestration in Central Asia; Lal, R., Suleimenov, M., Stewart, B.A., Hansen, D.O., Doraiswamy, P., Eds.; CRC Press: Boca Raton, FL, USA, 2007; pp. 127-136.

18. Saljnikov, E.; Saljnikov, A.; Rahimgalieva, S.; Cakmak, D.; Kresovic, M.; Mrvic, V.; Dzhalankuzov, T. Impact of Energy Saving Cultivations on Soil Parameters in Northern Kazakhstan. Energy 2014, 77, 35-41. [CrossRef]

19. Ogle, S.M.; Alsaker, C.; Baldock, J.; Bernoux, M.; Breidt, F.J.; McConkey, B.; Regina, K.; Vazquez-Amabile, G.G. Climate and Soil Characteristics Determine Where No-Till Management Can Store Carbon in Soils and Mitigate Greenhouse Gas Emissions. Sci. Rep. 2019, 9, 11665. [CrossRef]

20. Kiryushin, V.I. Minimization of tillage: Perspectives and contradictions. Agriculture 2006, 5, 2-14.

21. Suleimenov, M.K.; Kaskarbaev, Z.A. Diversification of crop production and conservation agriculture-the basis for ensuring food security. In Proceedings of the Diversification of Crop Production and No-till as the Basis of Conservation Agriculture and Food Security, Shortandy-Astana, Kazakhstan, 23-24 July 2011; pp. 27-33.

22. Suleimenov, M.K. The use of plant residues in resource-saving technologies. In Proceedings of the Diversification of Crop Production and No-till as the Basis of Conservation Agriculture and Food Security, Shortandy-Astana, Kazakhstan, 23-24 July 2011; pp. 39-43.

23. Powlson, D.; Stirling, C.; Jat, M.; Gerard, B.G.; Palm, C.A.; Sanchez, P.A.; Cassman, K.G. Limited potential of no-till agriculture for climate change mitigation. Nature Clim. Change 2014, 4, 678-683. [CrossRef]

24. Kenenbaev, S.B.; Bastaubaeva, S.O. Priority areas in crop production and agriculture in connection with climate changes. In Proceedings of the Conference Dedicated to the 60th Anniversary of the Grain Farming Centre Named after A. I. Baraev: Agriculture and Selection of Agricultural Plants at the Present Stage, Astana-Shortandy, Kazakhstan, 9-10 July 2016; Volume I, pp. 41-45.

25. Malić, N.; Stamenković, U.M. Effect of nitrogen fertilizer on growth of seeded grassland dry biomass in process of deposol: Biological reclamation. Zemlj. Bilj. 2019, 68, 12-23. [CrossRef] 
26. Essel, B.; Abaidoo, R.C.; Opoku, A.; Ewusi-Mensah, N. Economically Optimal Rate for Nutrient Application to Maize in the Semi-deciduous Forest Zone of Ghana. J. Soil Sci. Plant Nutr. 2021, 20, 1703-1713. [CrossRef] [PubMed]

27. Rurinda, J.; Zingore, S.; Jirbin, J.M.; Balemi, T.; Masuki, K.; Andersson, J.A.; Mutegi, J.; Kamara, Y.A.; Vanlauwe, B.; Craufurd, P.; et al. Science-based decision support for formulating crop fertilizer recommendations in Sub-Saharan Africa. Agric. Syst. 2020, 180, 102790. [CrossRef]

28. Pandey, M.; Shrestha, J.; Subedi, S.; Shah, K.K. Role of nutrients in wheat: A review. Trop. Agrobiodiversity 2020, 1, 18-23. [CrossRef]

29. Salim, N.; Raza, A. Nutrient use efficiency (NUE) for sustainable wheat production: A review. J. Plant Nutr. 2019, 43, 297-315. [CrossRef]

30. Abelentsev, V.I. Without Seed Treatment, There Will Be No High-Quality Harvest. Field of August, 2007, no. 3. Available online: http:/ / www.avgust.com (accessed on 4 November 2021).

31. Tropova, E.Y.; Kazakova, O.A.; Vorobieva, I.G.; Selyuk, M.P. Fusarium root rot of grain crops in Western Siberia and the Trans-Urals. Plant Prot. Quar. 2013, 3, 23-26.

32. Porsev, I.N. Adaptive phytosanitary technologies for the cultivation of agricultural crops in the conditions of the Trans-Urals. In Monograph/Under the Editorship of VA Chulkina; Shadrinsky Publishing House: Shadrinsky, Russia, 2009; 320p.

33. Krupinsky, J.M.; Bailey, K.L.; Mcmullen, M.P.; Gossen, B.D.; Turkington, T.K. Managing plant disease risk in diversified cropping systems. Agron. J. 2002, 94, 198-209. [CrossRef]

34. Khoziev, A.Z.; Zaitseva, T.V.; Khakimullina, F.M. The role of seed treatment in the fight against root rot. Plant Prot. Quar. 2015, 3, 20-23.

35. Sydykov, M.A.; Sydyk, D.A. Direct sowing of winter wheat on rainfed lands of southern Kazakhstan. In Proceedings of the International Congress, “Global Climate Change and Biodiversity”, Almaty, Kazakhstan, 5-6 November 2015; pp. 177-182.

36. Meinel, T.; Christian, L.; Akshalov, K. Modern technologies for soil management and conservation in Northern Kazakhstan. In Novel Measurement and Assessment Tools for Monitoring and Management of Land and Water Resources in Agricultural Landscapes of Central Asia, Springer, Environmental Science; Mueller, L., Saparov, A., Lisheid, G., Eds.; Springer: Berlin/Heidelberg, Germany, 2014; pp. 455-464.

37. Nunes, M.R.; van Es, H.M.; Schindelbeck, R.; Ristow, A.J.; Ryan, M. No-till and cropping system diversification improve fi soil health and crop yield. Geoderma 2018, 328, 30-43. [CrossRef]

38. Blanco-Canqui, H.; Ruis, S.J. No-tillage and soil physical environment. Geoderma 2018, 326, 164-200. [CrossRef]

39. Li, J.; Wang, Y.; Guo, Z.; Li, J.; Tian, C.; Hua, D.; Shi, C.; Wang, H.; Han, J.; Xu, Y. Effects of conservation tillage on soil physicochemical properties and crop yield in an arid Loess Plateau, China. Sci. Rep. 2020, 10, 4716. [CrossRef]

40. Daryanto, S.; Wang, L.; Jacinthe, P.-A. No-till is challenged: Complementary management is crucial to improve its environmental benefits under a changing climate. Geogr. Sustain. 2020, 1, 229-232. [CrossRef]

41. Redkov, V.V. Soils of the Republic of Kazakhstan, 1960-1962; Academy of Sciences of the Republic of Kazakhstan, Soil Science Institute: Alma-Ata, Kazakhstan, 1964; Volumes 1-4.

42. WRB. World Reference Base for Soil Resources. World Soil Resources Reports No. 106; FAO: Rome, Italy, 2014; 189p.

43. Dospekhov, B.A. Workshop on Agriculture; Dospekhov, B.A., Vasiliev, I.P., Tulikov, A.M., Eds.; Agropromizdat: Moscow, Russia, 1987; 383p.

44. Grigoriev, A.I. Methodology for Variety Testing of Agricultural Crops. Issue 1. General Part; Kolos: Moscow, Russia, 1971; 248p.

45. Dospekhov, B.A. Field Experiment Technique; Agropromizdat: Moscow, Russia, 2011;315p.

46. Bobryshev, F.I.; Voiskovoy, A.I.; Dubina, V.V.; Dorozhko, G.R.; Popolus, G.P. Winter Wheat in the Stavropol Territory; Publishing House of SSAU "AGRUS": Stavropol, Russia, 2003; 307p.

47. Zelenskiy, N.A.; Zelenskaya, G.M.; Mokrikov, G.V. The effect of different tillage practices on yield of winter wheat. Available online: https:/ / web.snauka.ru/issues/2014/12/40834 (accessed on 23 October 2021).

48. Nurbekov, A.; Kassam, A.; Sydyk, D.; Ziadullaev, Z.; Dzhumshudov, I.; Mumindzhanov, K.; Feindel, D.; Turok, J. Practice of Soil Protecting and Resource-Saving Agriculture in Azerbaijan, Kazakhstan and Uzbekistan; FAO: Ankara, Turkey, 2016; 74p, ISBN 978-92-5-409247-4.

49. Stukalov, R.S. Efficiency of winter wheat cultivation depending on technology in the zone of unstable moistening of Stavropol region. Available online: https: / / elibrary.ru/item.asp?id=27698331 (accessed on 4 November 2021).

50. Penn, C.J.; Camberato, J.J. A Critical Review on Soil Chemical Processes that Control How Soil pH Affects Phosphorus Availability to Plants. Agriculture 2019, 9, 120. [CrossRef]

51. Rietra, R.P.J.J.; Heinen, M.; Dimkpa, C.O.; Bindraban, P.S. Effects of Nutrient Antagonism and Synergism on Yield and Fertilizer Use Efficiency. Commun. Soil Sci. Plant Anal. 2017, 48, 1895-1920. [CrossRef]

52. Rykov, V.B.; Kambulov, S.I.; Kambulov, I.A.; Kolesnik, V.V.; Demina, E.B.; Ridny, S.D.; Yankovsky, N.G. Productivity of winter wheat and methods of tillage. Grain Econ. Russ. 2015, 5, 63-65. (In Russian)

53. Sydykov, M.A. Economic Evaluation of the Efficiency of Winter Wheat Cultivation. In Proceedings of the XII International Scientific-Practical Conference on Agricultural Science for Agricultural Production in Kazakhstan, Siberia and Mongolia, Almaty, Kazakhstan, 16-17 April 2009; Bastau: Almaty, Kazakhstan, 2009; Volume I, pp. 232-234, (In Kazakh and Russian).

54. Kenenbaev, B.B.; Sydykov, M.A.; Sydyk, D.A. Productivity of winter wheat grown by direct sowing without tillage in the South Kazakhstan. Almaty Bastau Zharshy 2009, 9, 7-11. 